\title{
Identification of a soluble precursor complex essential for nuclear pore assembly in vitro
}

\author{
Marie-Christine Dabauvalle, Karin Loos, and Ulrich Scheer \\ Institute of Zoology I, University of Würburg, Röntgenring 10, W-8700 Würzburg, Federal Republic of Germany \\ Received Maly 8, 1990 \\ Accepted fuly 3, 1990 by W. Hennig
}

\begin{abstract}
We analysed the soluble form in which the nuclear pore complex protein p68 is stored in Xenopus laevis eggs and its involvement in pore complex assembly processes. We have shown previously that $\mathrm{p} 68$, which is the major wheat germ agglutinin (WGA)-binding glycoprotein of nuclear pore complexes from Xenopus oocytes, is located in the pore channel and participates in mediated transport of karyophilic proteins. Using a monoclonal antibody directed against p68 (PI1) we removed this protein from Xenopus egg extract by immunoadsorption. On addition of lambda DNA the immunodepleted extract supported reconstitution of nuclei which were surrounded by a continuous double-membrane envelope but lacked pore complexes and were unable to import karyophilic proteins such as nucleoplasmin or lamin $\mathrm{L}_{\mathrm{III}}$. Essentially identical results were obtained with extract depleted of WGA-binding proteins. Our finding that both the anti-p68 antibody and WGA efficiently removed components from the extract necessary for pore complex assembly but did not interfere with nuclear membrane formation demonstrates that these processes are independent of each other. Analysis of the immunoprecipitate on silver-stained SDS-polyacrylamide gels indicated that the antibody adsorbed other proteins besides p68, notably two high molecular weight components. By sucrose gradient centrifugation and gel filtration we showed that $p 68$ together with associated protein(s) forms a stable, approximately globular complex with an $\mathrm{M}_{\mathrm{r}}$ of 254,000, a Stokes radius of $5.2 \mathrm{~nm}$ and a sedimentation coefficient of $11.3 \mathrm{~S}$. Our finding that p 68 occurs in the form of larger macromolecular assemblies offers an explanation for the distinctly punctate immunofluorescence pattern observed in the cytoplasm of mitotic cells after staining with antibodies to p68.
\end{abstract}

\section{Introduction}

The nuclear envelope consists of the double-layered nuclear membrane, the lamina closely apposed to the nuc-

Offprint requests 1o: M.-C. Dabauvalle leoplasmic face of the inner nuclear membrane and numerous pore complexes traversing the perinuclear cisterna (for recent reviews see Gerace and Burke 1988; Kessel 1988; Scheer et al. 1988). During mitosis of higher eukaryotic cells the nuclear envelope and hence the compartmentalization barrier between nucleus and cytoplasm transiently breaks down ("open mitosis"). Disassembly of the nuclear membranes proceeds by a vesicularization process while the lamina depolymerizes into mono- or oligomeric constituents, probably as a result of hyperphosphorylation of the lamina proteins (for references see Gerace 1986; Gerace and Burke 1988; Newport and Spann 1987; Newport and Forbes 1987). In contrast, the fate of the nuclear pore complexes during mitosis is at present unknown. It is quite unlikely that they are simply released as intact macromolecular assemblies into the cytoplasm during nuclear envelope breakdown since individual, membrane-free pore complexes have not been detected in electron microscopic preparations (e.g. Roos 1973; Maul 1977; Zatsepina et al. 1977). Therefore, and in view of their exceptional stability even after experimental removal of the nuclear membrane (Krohne et al. 1981; Franke et al. 1981), the disappearance of the nuclear pore complexes during mitosis apparently involves an active process affecting their structural integrity. This notion receives further support from ultrastructural investigations showing that the loss of pore complexes may precede nuclear envelope breakdown (Szollosi et al. 1972; Zatsepina et al. 1977; Stafstrom and Staehelin 1984).

Upon breakdown of the nuclear envelope, pore complex material disperses throughout the cytoplasm of metaphase cells as shown by immunofluorescence microscopy (Gerace et al. 1982; Davis and Blobel 1986; Snow et al. 1987; Park et al. 1987; Benavente et al. 1989 a). However, as judged from the distinctly punctate pattern of fluorescence, pore complexes do not completely disintegrate but remain at least partly assembled in some kind of larger complex (Snow et al. 1987; Benavente et al. 1989a).

Extracts prepared from amphibian eggs represent a convenient source of large quantities of metaphase- or telophase-like cytoplasm (for review see Lohka and Maller 1987). Unfertilized amphibian eggs which are ar- 
rested in the metaphase of the second meiotic division contain the disassembled components of the nuclear envelope of the giant oocyte nucleus as well as a pool of other prefabricated materials required for the rapid assembly of embryonic nuclei. Fertilization or parthenogenetic activation releases the cell cycle arrest and the egg completes meiosis. Extracts prepared from activated (i.e. telophasic) amphibian eggs are capable of assembling not only nuclear envelopes around sperm chromatin (Lohka and Masui 1983; reviewed in Lohka and Maller 1987; Lohka 1988) but also nucleus-like structures upon addition of protein-free DNA (Newmeyer et al. 1986a; Newport 1987). The reconstitution of nuclear structures around added DNA is a sequential process involving a number of intermediate steps such as packaging the DNA with stored histones into nucleosomes before a nuclear envelope is formed (Newport 1987).

The in vitro assembled nuclear envelopes are structural and functional reproductions of the natural nuclear envelope: they are composed of an inner and outer membrane, a lamina layer underlying the inner nuclear membrane and numerous pore complexes (Newmeyer et al. 1986a; Newport 1987; Lohka 1988; Newmeyer and Forbes 1988; Sheehan et al. 1988; for morphological aspects of the native nuclear envelope of Xenopus oocytes see Scheer et al. 1988). In addition, the in vitro reconstituted nuclei mimic the behaviour of normal nuclei in that they also transport karyophilic proteins through the pore complexes in a signal sequence and energy dependent manner (Newmeyer et al. 1986b; Newmeyer and Forbes 1988).

Recently a group of pore complex glycoproteins with cytoplasmically or nucleoplasmically exposed O-linked $\mathrm{N}$-acetylglucosamine (GlcNAc) residues has been identified (Davis and Blobel 1987; Hanover et al. 1987; Holt et al. 1987; Park et al. 1987; Snow et al. 1987; Scheer et al. 1988; for review see Hart et al. 1989). Members of this glycoprotein family are located within the pore channel proper and appear to be part of the pore transport machinery since nuclear protein uptake is inhibited by wheat germ agglutinin (WGA), a lectin which binds to their GlcNAc sugar moieties. WGA blocks the nuclear import of karyophilic proteins not only in cell free systems (Finlay et al. 1987; Newmeyer and Forbes 1988) but also in living cells after microinjection (Yoneda et al. 1987; Dabauvalle et al. 1988a; Wolff et al. 1988). Among the WGA-binding pore complex glycoproteins of Xenopus oocytes we have recently identified a major component of $\mathrm{Mr} 68,000$ (p68) which is confined to the pore channel and crucially involved in nuclear protein transport processes (Dabauvalle et al. $1988 \mathrm{~b}$; see also Featherstone et al. 1988). This pore complex glycoprotein is evolutionarily highly conserved and has been detected in a variety of species ranging from insects to mammals by means of immunofluorescence and immunoblotting studies employing the monoclonal antibody PI1 (Chaly et al. 1984, 1986; Benavente et al. 1989a, b; Dabauvalle et al. 1988 b). Furthermore, microinjection of antibody PI1 inhibited nuclear protein uptake not only in Xenopus oocytes (Dabauvalle et al. 1988 b) but also in mammalian cells (Benavente et al. 1989a, b).
By using the cell-free Xenopus egg extract in conjunction with pore-specific antibodies it should be feasible to characterize the soluble state of various pore complex constituents during metaphase/anaphase, to purify these components and to analyse their interaction with and mode of insertion into the nuclear membranes during the process of pore complex formation. As a first step towards this goal we investigated the molecular state of p68 in the extract and followed nuclear envelope formation in the absence of this pore complex protein.

\section{Materials and methods}

Animals. African clawed toads ( $X$. laevis) were purchased from the South African Snake Farm (Fish Hoek, Cape province, South Africa).

Antibodies. The monoclonal antibody PII (IgM) has been described previously (Chaly et al. 1984, 1986). It recognizes a major GlcNAccontaining pore complex glycoprotein of $\mathrm{Mr} 68,000$ both from Xenopus oocytes (Dabauvalle et al. 1988b) and mammalian PtK2 cells (Benavente et al. 1989a). PI1 antibodies purified from ascites fluid by hydroxylapatite chromatography (Stanker et al. 1985) were kindly provided by N. Chaly (Carleton University, Ottawa, Canada). Monoclonal murine antibody $\mathrm{S} 49 \mathrm{H} 2$ which recognizes specifically Xenopus lamin $\mathrm{L}_{\mathrm{III}}$ and guinea pig antibodies directed against Xenopus nucleoplasmin (Krohne and Franke 1980) were obtained from G. Krohne (German Cancer Research Center, Heidelberg). Monoclonal murine antibody AK30-10 against DNA (for details see Scheer et al. 1987) was purchased from Progen (Heidelberg, FRG) or Boehringer Mannheim.

Nuclear reconstitution. Extracts were prepared from de-jellied Xenopus eggs $20 \mathrm{~min}$ after parthenogenetic activation by electric shock (Karsenti et al. 1984) essentially as described by Newport (1987). Good extracts which promoted the assembly of a large number of nuclei upon addition of DNA were frozen in aliquots at $-70^{\circ} \mathrm{C}$ and used throughout the experiments. We noticed no substantial loss of biological activity of frozen and rapidly thawed batches as compared with fresh aliquots within 2 months. Bacteriophage lambda DNA (Gibco-BRL, Eggenstein, FRG) was processed and mixed with the extract to promote nuclear reconstitution as detailed by Newport (1987). After an incubation period of $2 \mathrm{~h}$ the in vitro formed nuclei were examined by immunofluorescence or electron microscopy.

Depletion of the egg extracts. Antibody PI1 was coupled to CNBRactivated Sepharose 4B according to the manufacturer's instructions (Pharmacia, Freiburg, FRG). WGA-Sepharose 6MB was purchased from Pharmacia. In order to remove pore complex proteins from the egg extract, $100 \mu \mathrm{l}$ of extract was incubated with either antibody PI1-Sepharose $(100 \mathrm{mg}$ of Sepharose containing ca. 300 $\mu \mathrm{g}$ of PI1) or $200 \mu \mathrm{l}$ of WGA-Sepharose. After $1 \mathrm{~h}$ incubation at room temperature the Sepharose was removed by centrifugation. For controls, extract was incubated with non-immune IgM (Calbiochem, Frankfurt, FRG) coupled to CNBR-activated Sepharose 4B in the same fashion.

In some experiments, $10 \mu \mathrm{l}$ of a WGA $(2 \mathrm{mg} / \mathrm{ml})$ or antibody PI1 solution $(10 \mathrm{mg} / \mathrm{ml})$ was added directly to $100 \mu \mathrm{l}$ of extract prior to incubation with DNA.

Proteins bound to antibody PI1 or control IgM were recovered by resuspending the antibody-Sepharose pellet for $5 \mathrm{~min}$ at room temperature in $100 \mu \mathrm{l}$ of $3 \mathrm{M} \mathrm{KSCN}$. After centrifugation $(1,700 \mathrm{~g}$, $5 \mathrm{~min}$ ), supernatant proteins were dialysed and concentrated to dryness by pressure filtration (Sartorius, Göttingen, FRG). Then they were resuspended in $15 \mu 1$ of sample buffer (Laemmli 1970) and analysed by SDS-polyacrylamide gel electrophoresis. WGAbinding proteins were eluted by adding GlcNAc to $100 \mathrm{mg} / \mathrm{ml}$ 
and analysed accordingly. The polypeptide pattern of the immunoor lectin-depleted extracts was analysed by SDS-polyacrylamide gel electrophoresis following acetone precipitation of small aliquots.

Sucrose gradient centrifugation. Egg extract $(0.1 \mathrm{ml})$ was diluted with $0.4 \mathrm{ml}$ buffer I ( $10 \mathrm{mM}$ Pipes, $50 \mathrm{mM} \mathrm{KCl}, 2.5 \mathrm{mM} \mathrm{MgCl}_{2}$, $1 \mathrm{mM}$ dithiothreitol, $\mathrm{pH} 7.4$ ) and layered on top of a linear $5 \%-$ $30 \%(\mathrm{w} / \mathrm{v})$ sucrose gradient made up in the same buffer. After centrifugation at $35,000 \mathrm{rpm}$ for $16 \mathrm{~h}$ at $4^{\circ} \mathrm{C}$ in a Beckman SW41 rotor, $0.5 \mathrm{ml}$ fractions were collected. Aliquots were either used for ELISA tests (see below) or precipitated in ice-cold 15\% trichloroacetic acid, washed with cold acetone, air dried and analysed by SDS-polyacrylamide gel electrophoresis. For S value determination marker proteins were run in parallel gradients (BSA 4.3 S; IgG 6.5 S; catalase $11.3 \mathrm{~S}$; thyroglobulin $16.5 \mathrm{~S}$ ).

Gel filtration. Sucrose gradient fractions containing the pore complex protein p68 were pooled, concentrated to a volume of 0.5 $\mathrm{ml}$ by vacuum dialysis (Sartorius) and loaded onto a Sephadex G200 (Pharmacia) column $(100 \times 1.5 \mathrm{~cm})$ equilibrated with buffer I. The column was eluted at a flow rate of $4 \mathrm{ml} / \mathrm{h}$ and $4 \mathrm{ml}$ fractions were collected and analysed by ELISA. The void volume was determined using Dextran Blue and the following proteins served as
$M_{r}$ standards (BSA 68,000; catalase 232,000; ferritin 440,000; thyroglobulin 660,000$)$.

Enzyme-linked immunosorbent antibody assay (ELISA). The ELISA assay was performed according to Hautanen and Linder (1981). Briefly, activated microtiter plates (Flow Laboratories, Meckenheim, FRG) were coated with aliquots of either sucrose gradient or gel filtration fractions $(50 \mu \mathrm{l} /$ well $)$. Plates were then incubated with antibody PI1 at a concentration of $15 \mu \mathrm{g} / \mathrm{ml}$. As secondary antibodies, alkaline phosphatase-coupled anti-mouse IgG/IgM (Medac, Hamburg, FRG) were used at a dilution of 1:1,000. Specifically bound antibodies were visualized by enzyme reaction and absorbance was measured at $405 \mathrm{~nm}$ with a Titertek Multiscan photometer (Flow Laboratories).

Gel electrophoresis of proteins and immunoblotting. The protein composition of total or subfractionated egg extract, oocytes, and manually isolated nuclei and nuclear envelopes from Xenopus oocytes was analysed by SDS- $10 \%$ polyacrylamide gel electrophoresis (Laemmli 1970) followed by Coomassie Blue staining. Polypeptides present in the immunoprecipitates were visualized by the silver staining procedure according to Switzer et al. (1979). For immunoblotting experiments, polypeptides on one-dimensional SDS-polyacrylamide gels were electrophoretically transferred to nitrocellu-
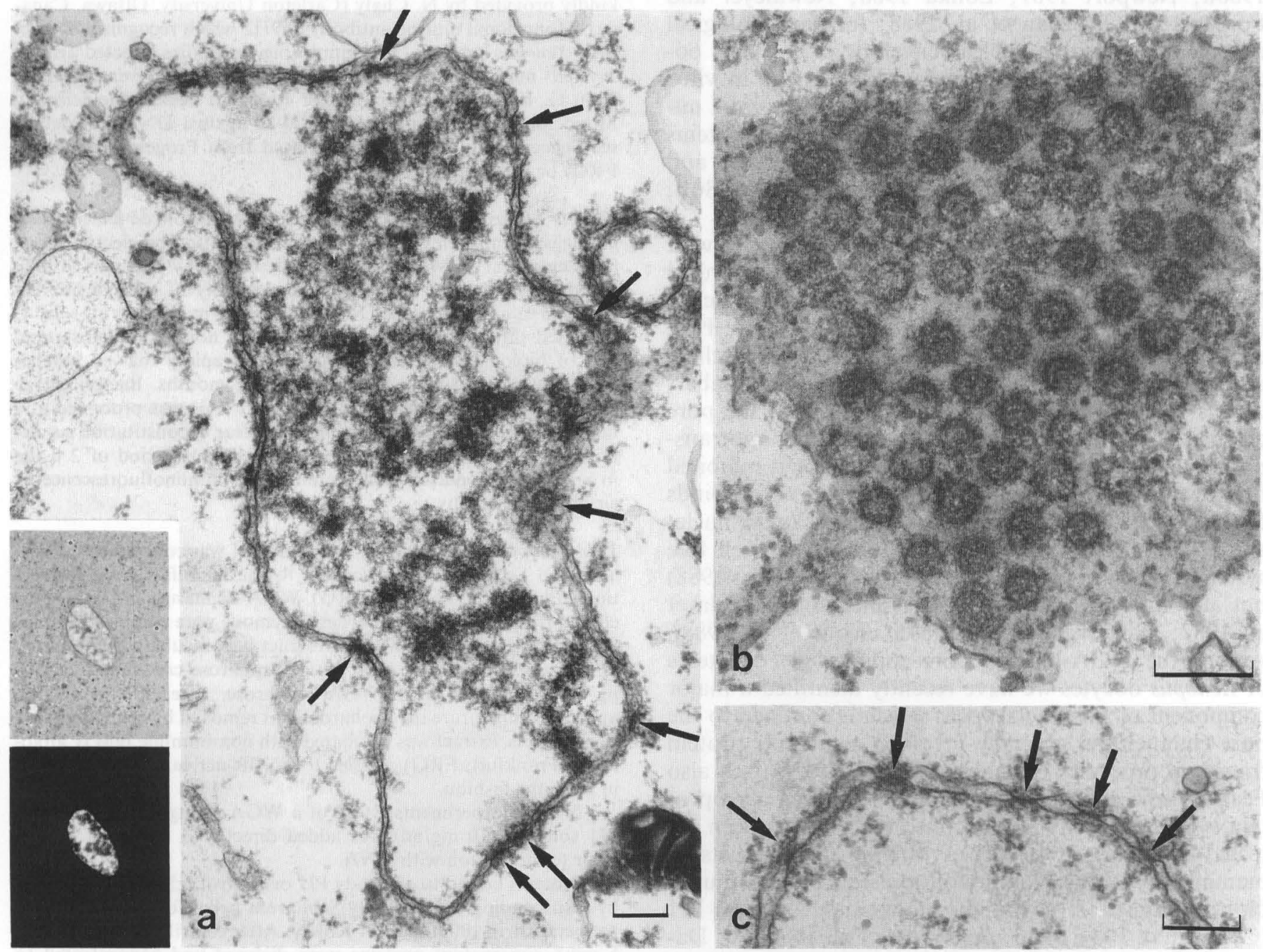

Fig. 1 a-c. In vitro reconstituted nuclei 90 min after addition of lambda DNA to egg extract as seen with phase contrast optics or fluorescence illumination after Hoechst staining (insert in a) and electron microscopy a-c. The nuclear envelope contains nu- merous pore complexes (arrows). Tangential sections reveal a remarkably high packing density of the pores $\mathbf{b}$. Bars represent $0.2 \mu \mathrm{m}$ 
lose paper according to Towbin et al (1979). The filters were blocked over night at $4^{\circ} \mathrm{C}$ using $10 \%$ nonfat dry milk in $140 \mathrm{mM}$ $\mathrm{NaCl}$ buffered with $10 \mathrm{mM}$ Tris-HCl to pH 7.4 (TBS). After a brief wash step in TBS, blots were incubated at room temperature with antibody PI $(10 \mu \mathrm{g} / \mathrm{ml}$ in TBS containing $10 \%$ milk and $0.3 \%$ Tween 20 ) for $2 \mathrm{~h}$ and washed sequentially with TBS (three times for $10 \mathrm{~min}$ each), $1 \mathrm{M} \mathrm{NaCl}, 0.5 \%$ Triton $\mathrm{X}-100,10 \mathrm{mM}$ Tris- $\mathrm{HCl}, \mathrm{pH} 7.4(30 \mathrm{~min})$ and again TBS (once for $30 \mathrm{~min}$ and twice for $10 \mathrm{~min}$ each). Peroxidase-conjugated anti-mouse $\operatorname{lgM} / \operatorname{IgG}$ (Medac, Hamburg, FRG) diluted 1:1,000 in the TBS/milk/Tween solution was then added for $45 \mathrm{~min}$. Filters were then washed with TBS (twice for $10 \mathrm{~min}$ each), the high salt buffer specified above $(30 \mathrm{~min})$. TBS containing $0.1 \%$ Triton $\mathrm{X}-100$ (three times for $10 \mathrm{~min}$ each $)$ and finally TBS $(10 \mathrm{~min})$. Bound antibodies were then visualized using 4-chloro-1-naphthol in the presence of $\mathrm{H}_{2} \mathrm{O}_{2}$ (Hawkes et al. 1982).

Immunofluorescence microscopy. After incubation with DNA the extract was fixed by dilution with 4 vol. PBS containing $3 \%$ formaldehyde (freshly prepared from paraformaldehyde). Nuclei were adsorbed to a coverslip by centrifugation for $15 \mathrm{~min}$ at $1,000 \mathrm{rpm}$ in a cytocentrifuge (Cytospin 2, Shandon, Frankfurt, FRG). Specimens were then fixed in acetone at $-20^{\circ} \mathrm{C}$ for $10 \mathrm{~min}$, air dried and incubated for $15 \mathrm{~min}$ each with antibodies directed against nucleoplasmin or lamin $L_{I I I}$ followed by the appropriate secondary antibodies conjugated to Texas Red (Dianova, Hamburg, FRG). Distribution of DNA was monitored either by staining with Hoechst $33258(5 \mu \mathrm{g} / \mathrm{m}$ l PBS) or by immunostaining with a monoclonal anti-DNA antibody $(10 \mu \mathrm{g} / \mathrm{ml}$; cf. Scheer et al. 1987). Photographs were taken with a Zeiss Axiophot (Carl Zeiss, Oberkochen, FRG) equipped with epifluorescence optics and the appropriate filter sets.

Electron microscopy. Samples $(50 \mu 1$ each) were fixed by fourfold dilution with $2.5 \%$ glutaraldehyde in $0.2 \mathrm{M}$ cacodylate buffer, $\mathrm{pH}$ 7.4 for $30 \mathrm{~min}$ at $4^{\circ} \mathrm{C}$. Nuclei were pelleted by centrifugation for $10 \mathrm{~min}$ at $3,000 \mathrm{~g}$. The pellet was then resuspended in a drop of liquid $2 \%$ low melting agarose (Gibco-BRL) prepared in 0.2
$\mathrm{M}$ cacodylate buffer at $30^{\circ} \mathrm{C}$. After solidifying the agarose by chilling, the samples were fixed again in glutaraldehyde $(5 \mathrm{~min})$ followed by $2 \% \mathrm{OSO}_{4}(15 \mathrm{~min})$, dehydrated through a graded ethanol series and finally embedded in Epon. Ultrathin sections were stained according to standard protocols and examined in a Zeiss EM 10 electron microscope.

\section{Results}

Removal of proteins binding to antibody PII or WGA from the egg extract abolishes pore complex formation

Each batch of Xenopus egg extract was initially tested for its ability to promote assembly of nuclei from added bacteriophage lambda DNA by phase contrast, fluorescence and electron microscopy. Representative examples are shown in Fig. 1. In the light microscope, reconstituted nuclei were visible $90 \mathrm{~min}$ after addition of DNA as spheroidal clear zones which fluoresced after staining with the DNA fluorochrome Hoechst 33258 (Fig. 1a, insert; see also Newport 1987; Newmeyer et al. 1986a). At the electron microscopic level chromatin appeared in the form of numerous dense aggregates interconnected by less dense strands (Fig. 1 a). The nuclear envelope contained a large number of pore complexes as illustrated in tangential (Fig. 1 b) and transverse (Fig. $1 \mathrm{a}, \mathrm{c})$ sections. However, pore complexes were not restricted to the nuclear envelopes of newly assembled nuclei but occurred also in the extranuclear cytosol in the form of annulate lamellae, either as single or stacked membrane cisternae (Fig. 3b; for a detailed account of annulate lamellae see Kessel 1989).

After immunodepletion of the egg extract of proteins binding to antibody PI1, nuclei formed normally with

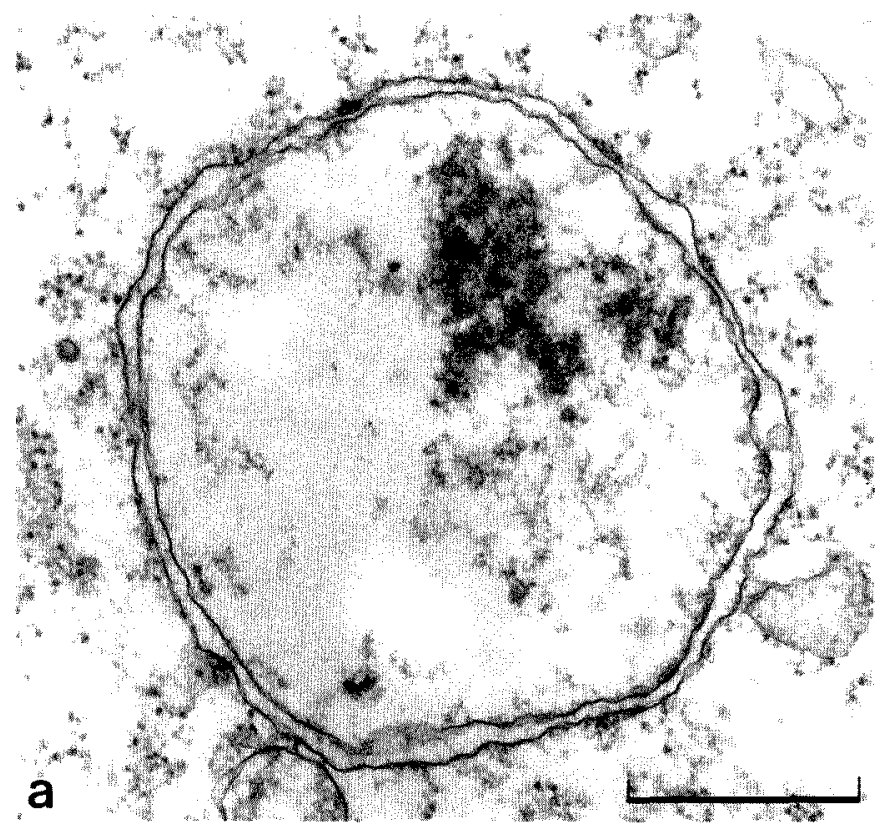

Fig. 2a, b. Representative electron micrographs of nuclei reconstituted under different conditions. Nuclei surrounded by a doublelayered nuclear envelope but lacking pore complexes are formed from immunodepleted extract a whereas apparently normal nuclei with pores are created when complete extract containing antibody

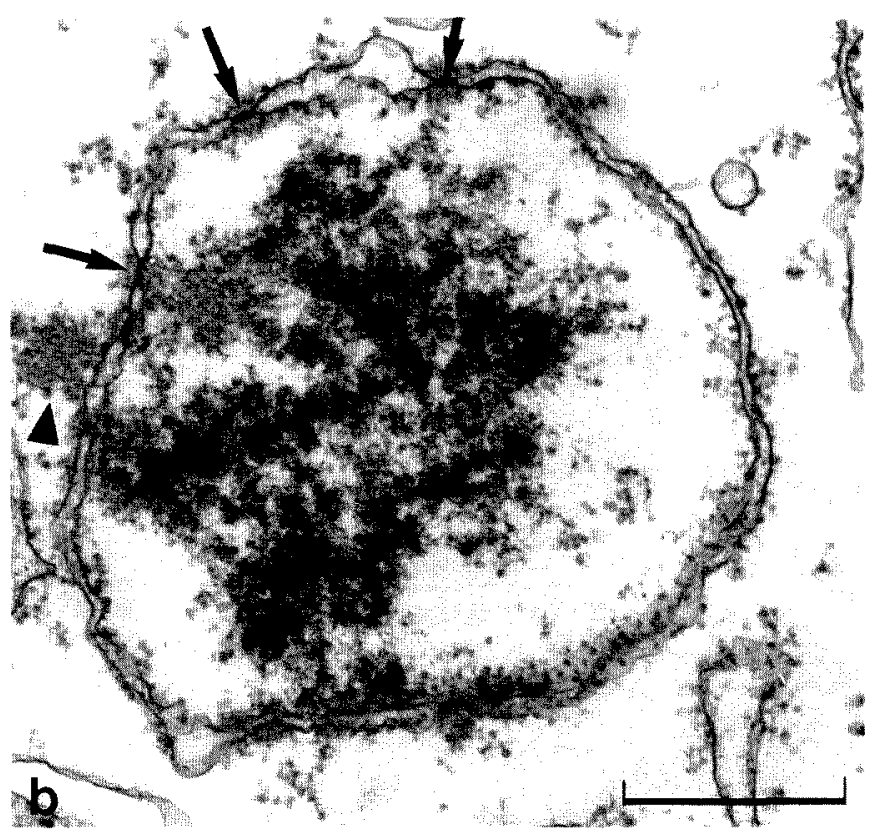

PI1 is used (b; some pores are denoted by arrows). A granular aggregate (arrowhead) is attached to the nucleus shown in b. Occasionally, such aggregates may also be trapped within a nucleus b. Bars represent $0.5 \mu \mathrm{m}$ 

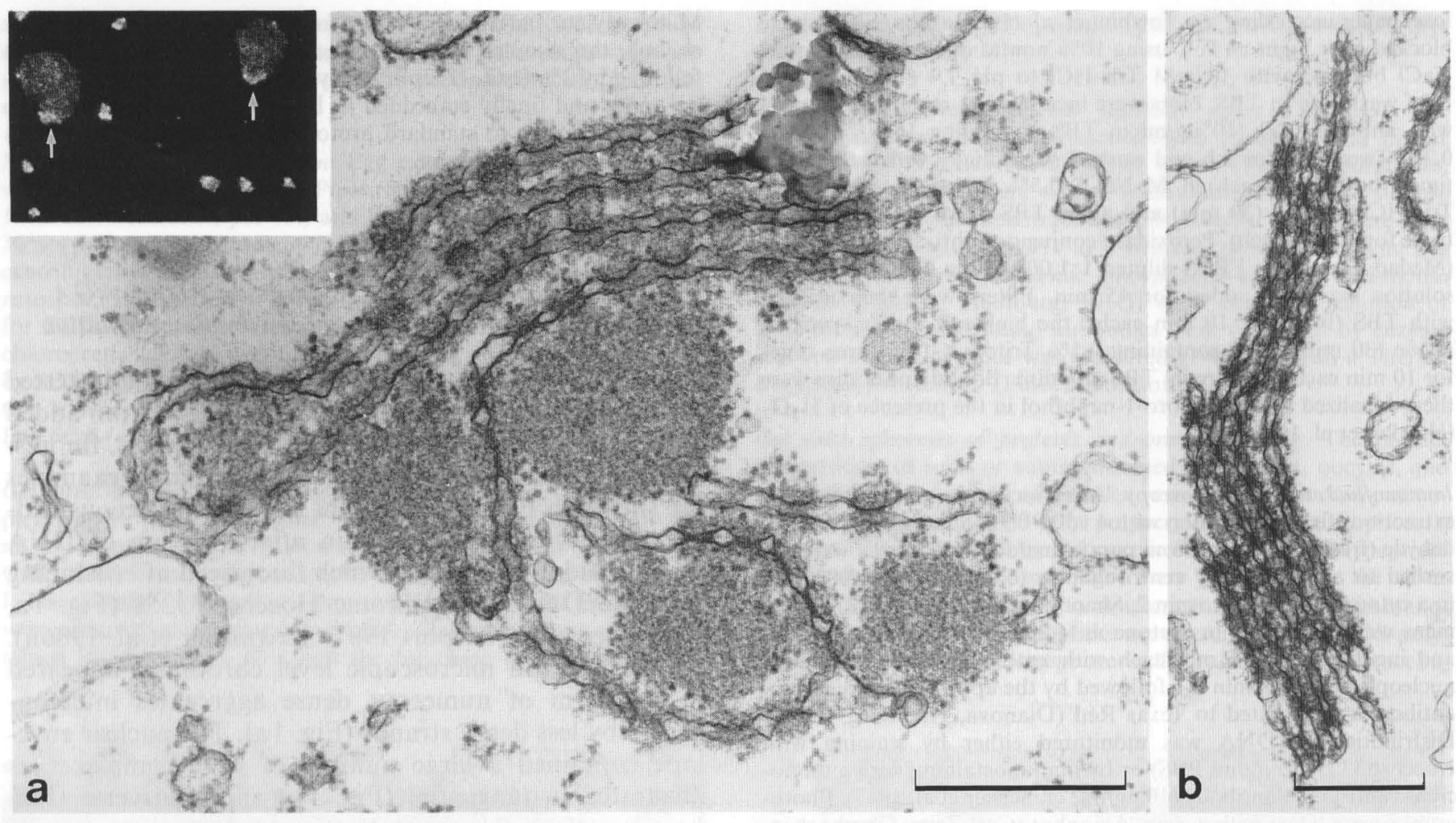

Fig. 3a, b. Electron micrographs of annulate lamellae formed in egg extract containing antibody PI 1 a and in control preparations lacking antibodies $\mathbf{b}$. Large granular aggregates with distinct 12-15 $\mathrm{nm}$ particles attached to their surfaces are in close contact with the pore complexes of the annulate lamellae a but are absent from

control preparations b. Immunofluorescence microscopy reveals that antibody PI1 forms discrete entities distributed throughout the cytosol and attached to reconstituted nuclei (insert in a, arrows). Bars represent $0.5 \mu \mathrm{m}$

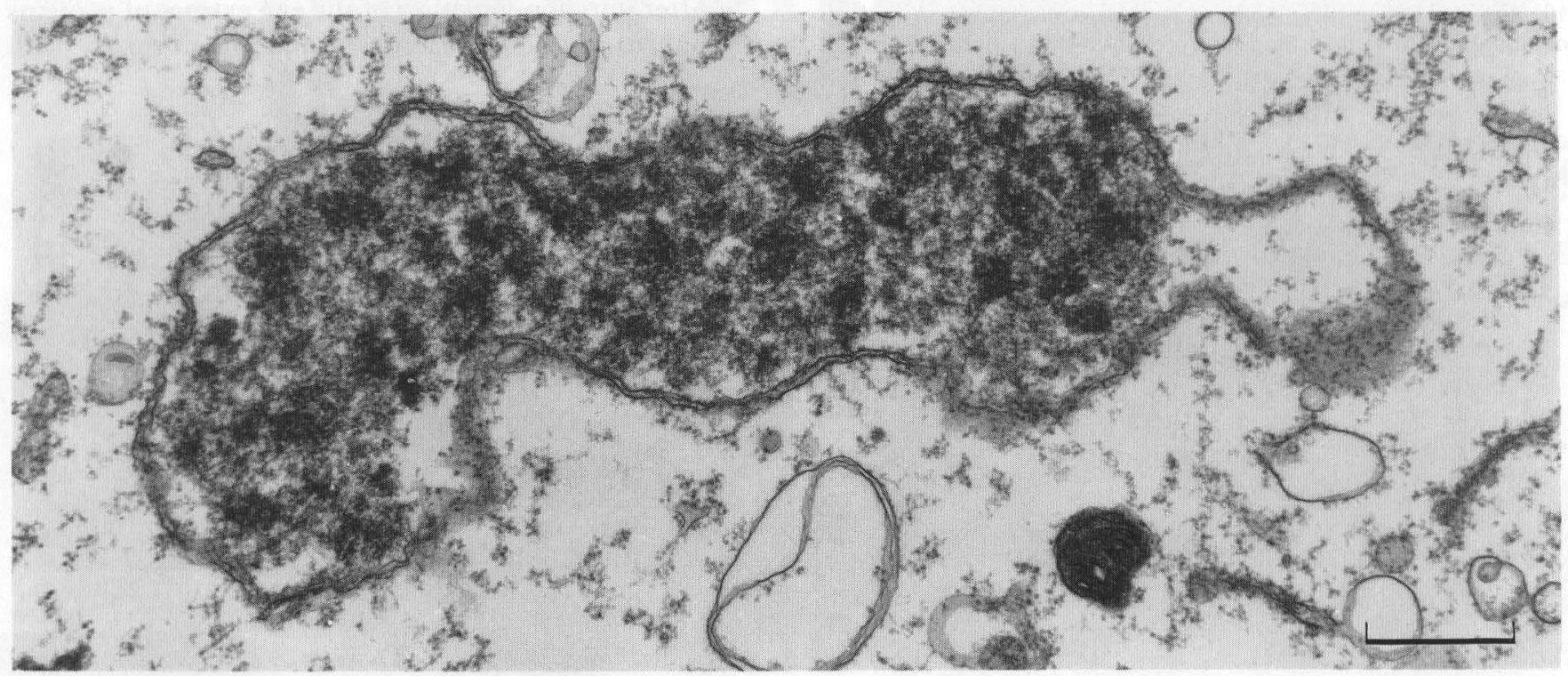

Fig. 4. Electron micrograph showing a nucleus reconstituted in egg extract depleted of wheat germ agglutinin (WGA)-binding glycoproteins. Note the absence of pore complexes. Bar represents $0.5 \mu \mathrm{m}$

only one notable exception: the double-layered nuclear envelope consistently lacked pore complexes (Fig. 2a). Controls, in which antibody PI1 was replaced by irrelevant antibodies allowed reconstitution of complete nuclear envelopes with nuclear pore complexes. When DNA incubation was performed in complete extract with added antibody, apparently normal nuclei with numerous pore complexes formed (Fig. $2 b$ ) indicating that antibody binding to p68 per se did not interfere with pore complex assembly processes. Addition of antibody PI1 to the extract caused the appearance of numerous aggregates with a finely granular texture and larger par- 
ticles (12 to $15 \mathrm{~nm}$ in diameter) attached to their surfaces, often in close association with annulate lamellae (Fig. 3 a) and reconstituted nuclei (Fig. 2 b). The striking association of these aggregates with pore complexes of newly formed nuclei as well as of annulate lamellae pointed to their nature as antibody complexes (similar aggregates surrounded by pore-containing membranes have been found after microinjection of antibody PI1 into cultured mammalian cells; Benavente et al. 1989 b). Indeed, after incubation of extract with Texas Red-conjugated antibodies against mouse $\operatorname{IgM}$, immunofluorescence microscopy revealed numerous fluorescent entities distributed throughout the cytosol and juxtaposed to the reconstituted nuclei (Fig. $3 \mathrm{a}$, insert) in a pattern consistent with the distribution of the granular aggregates observed in electron microscopic sections. In control preparations nuclei and annulate lamellae were free of the attached granular material (Fig. 3 b). As a corollary, it can be concluded that p68 is also a constituent of the pore complexes of annulate lamellae.

For comparison we also used egg extract depleted of WGA-binding proteins. Again, the reconstituted nuclei were surrounded by a continuous double membrane envelope which lacked pore complexes (Fig. 4). Identical results were obtained with complete extract in the presence of WGA.

\section{Nuclei formed in depleted extract are defective for transport}

While the above studies showed, by morphological criteria, that removal of WGA- or antibody PI1-binding proteins from the extract inhibited pore complex formation we sought to confirm this finding by an independent functional test. Under control conditions the in vitro assembled nuclei actively accumulated the karyophilic protein nucleoplasmin from the cytosolic milieu as demonstrated by immunofluorescence microscopy (Fig. $5 \mathrm{a}^{\prime \prime}$; see also Newmeyer et al. $1986 a$, b). In contrast, nuclei formed from extract immunodepleted with PI1 antibodies were unable to transport and to accumulate nucleoplasmin (Fig. 5b"). Essentially identical results were obtained with unfractionated extract in the presence of PI1 and with WGA-depleted or WGA-containing extract (not shown).

The inability of nuclei reconstituted from depleted extracts to transport and accumulate proteins was further illustrated by using antibodies to lamin $\mathrm{L}_{\mathrm{III}}$, the only lamina protein species present in Xenopus egg extracts (Benavente et al. 1985; Stick and Hausen 1985). Under control conditions lamin antibodies strongly stained the periphery of the reconstituted nuclei (Fig. $6 \mathrm{a}^{\prime}$; see also Newport 1987). In contrast, nuclei assembled from extracts depleted of WGA- or PI1-binding proteins were negative with the lamin antibodies (Fig. $\left.6 b^{\prime}, c^{\prime}\right)$. These data demonstrate that formation of a normal nuclear lamina requires the uptake of soluble lamins through the pore complexes (see also Krohne et al. 1989).

Taken together, our findings show that antibody PI1 and WGA efficiently adsorb out of the Xenopus egg extract components necessary for pore complex formation without affecting nuclear membrane assembly. Unfortunately, we have so far been unable to reconstitute the

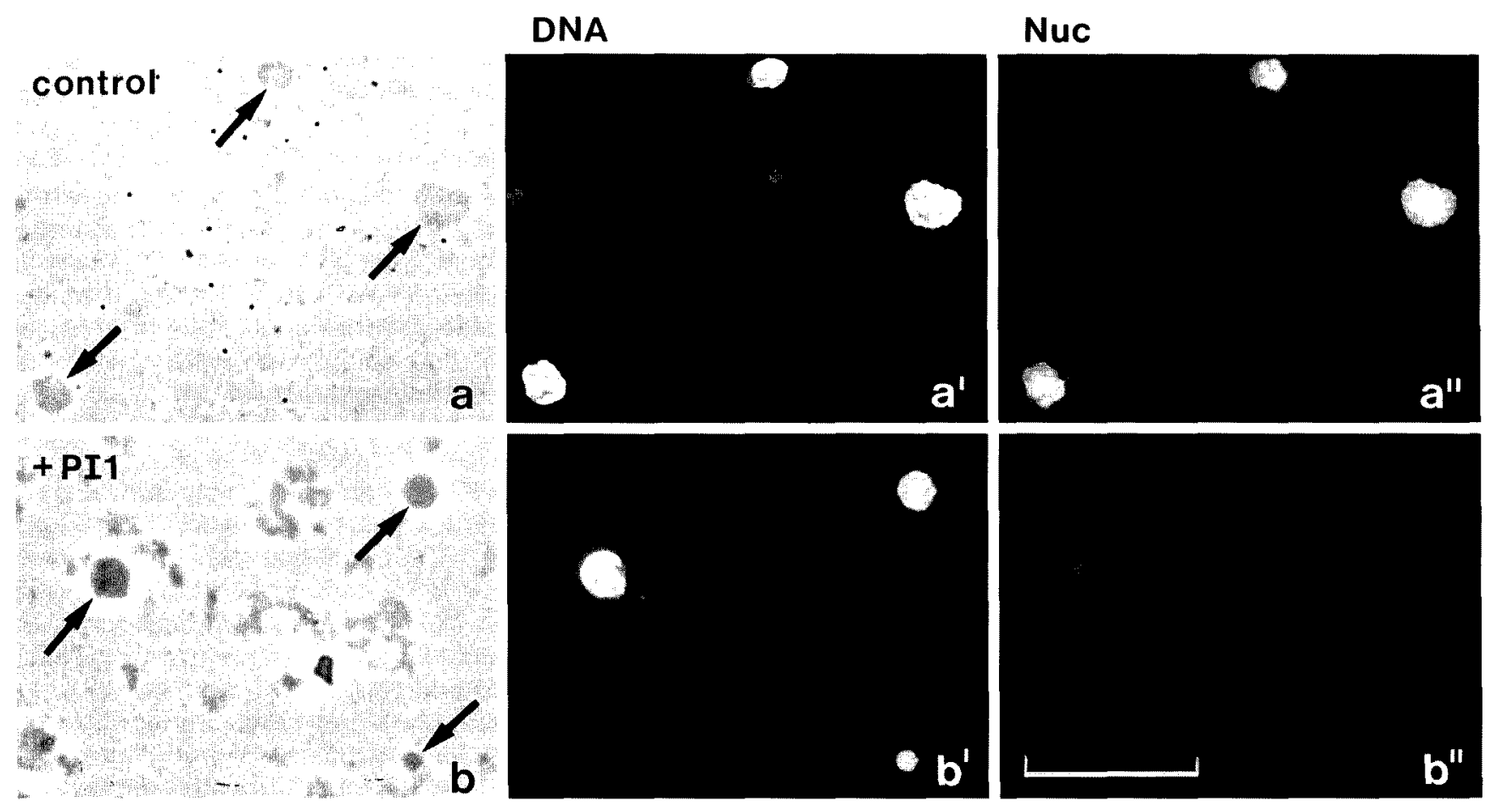

Fig. 5a, b. Nucleoplasmin is accumulated in nuclei reconstituted from control extract a but not from extract immunodepleted of Pl1-binding proteins $\mathbf{b}$. Nuclei (arrows) are shown in phase contrast $\mathbf{a}, \mathbf{b}$ and in immunofluorescence using antibodies to DNA $\mathbf{a}^{\prime}, \mathbf{b}^{\prime}$ and nucleoplasmin $\mathbf{a}^{\prime \prime}, \mathbf{b}^{\prime \prime}$. Bar represents $20 \mu \mathrm{m}$ 
DNA
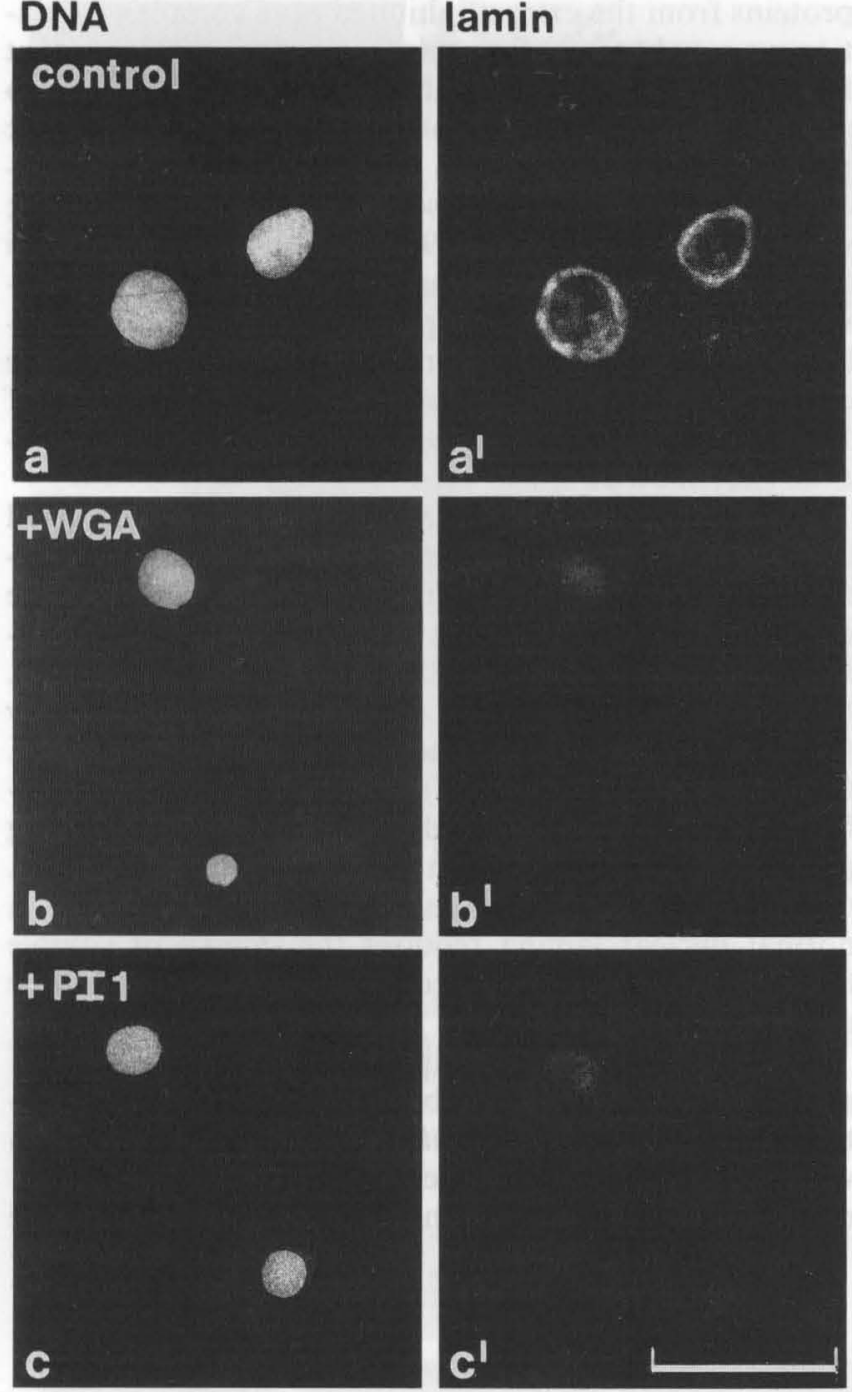

Fig. 6a-c. Inhibition of lamina formation in nuclei reconstituted in extracts depleted of proteins binding to WGA $\mathbf{b}^{\prime}$ and antibody PI1 $\mathbf{c}^{\prime}$ as shown by immunofluorescence microscopy using antibodies to lamin $\mathrm{L}_{\mathrm{III}}$. Control nuclei reveal a prominent lamina $\mathbf{a}^{\prime}$. Hoechst fluorescence of the nuclei is shown in a-c. Bar represents $20 \mu \mathrm{m}$

ability of depleted extracts to promote pore complex formation by adding back proteins eluted from PI1- or WGA-Sepharose.

\section{p68 occurs in the form of a stable supramolecular complex}

Analysis of the proteins bound to antibody PI1-Sepharose by SDS-polyacrylamide gel electrophoresis and silver staining revealed a complex pattern (Fig. 7, lane 4). Comparison with control immunoprecipitations using non-immune IgM showed that besides p68 at least three other proteins were specifically immunoadsorbed by PI1 (denoted by arrows in Fig. 7, lane 4). The two high molecular weight components comigrated with major polypeptides of manually isolated nuclear envelopes from Xenopus oocytes (Fig. 7, lane 5; see also Krohne

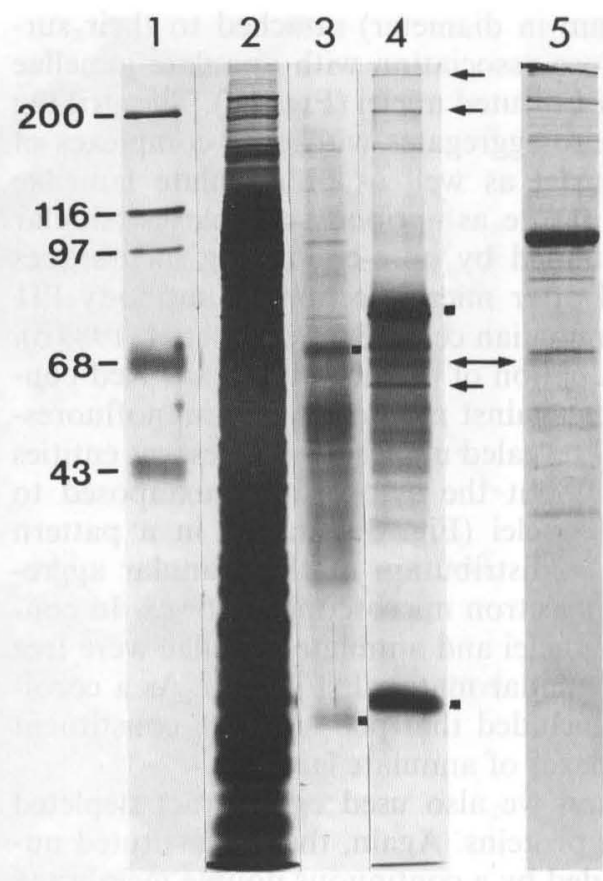

Fig. 7. Gel electrophoretic analysis of proteins immunoadsorbed from egg extract by antibody PI1-Sepharose (lane 4; double-headed arrow indicates the position of p68; the three small arrows denote polypeptides specifically adsorbed by the antibody; the two polypeptide bands denoted by dots represent the heavy and light chains of IgM molecules which dissociated from the Sepharose during the elution process). Polypeptides adsorbed by an irrelevant monoclonal IgM are shown in lane 3 (immunoglobulin light and heavy chains are indicated by dots). Unbound proteins were run in lane 2. For comparison, the protein pattern of 200 manually isolated nuclear envelopes from Xenopus oocytes is shown in lane 5 (the position of $\mathrm{p} 68$ which runs slightly ahead of the prominent lamin band is indicated by the double-headed arrow; the major polypeptide of this preparation is contaminating yolk). Lanes $1-4$, silver staining; lane 5, Coomassie blue staining. Molecular mass markers are shown in lane 1 (values indicated in $\mathrm{kDa}$ )

et al. 1981). When proteins bound to WGA-Sepharose were eluted and analysed by silver staining, the resulting pattern was still more complex (not shown). This was not surprising since WGA recognizes the common GlcNAc sugar residue and thus binds non-selectively to the whole family of pore complex glycoproteins as well as other GlcNAc-bearing proteins known to occur in the cytoplasm and nucleoplasm of cells (Hart et al. 1989).

Since antibody PI1 has previously only been characterized by immunoblotting on isolated nuclear envelopes (Dabauvalle et al. 1988b), we first performed experiments to verify that it recognized the same antigen in Xenopus egg extract. Total proteins of extracts from activated and non-activated eggs were separated by gel electrophoresis, blotted and probed with antibody PI1. As illustrated in Fig. 8 (lanes $1^{\prime}$ and 2'), the antibody recognized an $M_{r} 68,000$ component which most likely represents p68 since we could also confirm the presence of GlcNAc-sugar residues by WGA blotting (data not shown). In addition, a polypeptide of $M_{r} 42,000$ was also labelled on the immunoblots. Essentially identical 


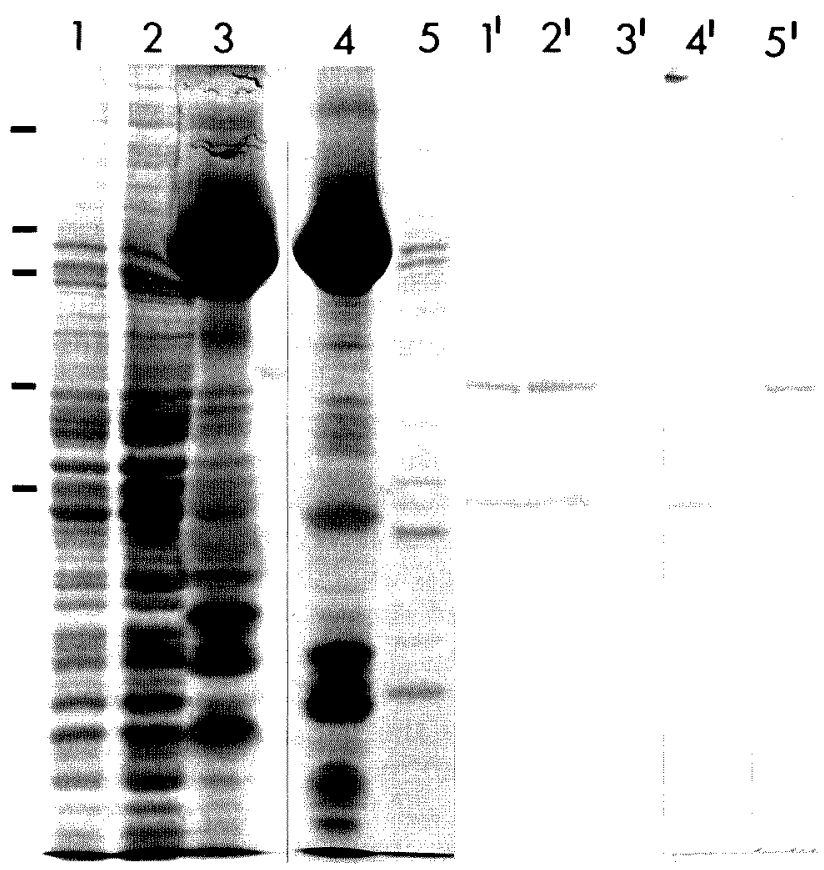

Fig. 8. Immunoblotting of extract from non-activated (lane 1 ) or activated (lane 2) Xenopus eggs, total oocytes (lane 3), manually separated oocyte cytoplasm (lane 4) and nuclei (lane 5) with monoclonal antibody PI1. After SDS-polyacrylamide gel electrophoresis the gels were either stained with Coomassie Blue (lanes 1-5) or blotted onto nitrocellulose and probed with antibody PI1 (lanes $\left.I^{\prime} 5^{\prime}\right)$. Bars to the left indicate, from top to bottom, the position of molecular mass markers (myosin heavy chain, $200 \mathrm{kDa} ; \beta$-galactosidase, $116 \mathrm{kDa}$; phosphorylase b, $97 \mathrm{kDa}$; bovine serum albu$\min , 68 \mathrm{kDa}$; ovalbumin, $43 \mathrm{kDa}$ )

results were obtained with homogenates of Xenopus oocytes (Fig. 8, lane $3^{\prime}$ ). When we examined the nucleocytoplasmic distribution of the two proteins reacting with antibody PI1 by probing nuclear and cytoplasmic fractions from oocytes separately, the $M_{r} 42,000$ protein was exclusively recovered from the ooplasmic fraction whereas nuclei contained only p68 (Fig. 8, lanes $4^{\prime}$ and $5^{\prime}$ ). The presence of $\mathrm{p} 68$ in the ooplasmic fraction might indicate the existence of a soluble cytoplasmic pool of p68 and/or reflect the occurrence of numerous pore complexes in cytoplasmic annulate lamellae (for references see Kessel 1989). We conclude that the $M_{r} 42,000$ cytoplasmic protein recognized by antibody PI1 in immunoblots is not a component of nuclear pore complexes.

The results of our immunoprecipitation experiments pointed to the existence of a larger supramolecular complex in the egg extract consisting of p68 as well some other proteins. In order to determine the size of this putative complex we subjected the egg extract to sucrose gradient centrifugation followed by ELISA detection of p68. As shown in Fig. 9a, p68 did not sediment as expected for a monomeric molecule but rather as a larger complex with a sedimentation coefficient of $11.3 \mathrm{~S}$. Gel electrophoresis clearly revealed the presence of p68 in the peak fraction of the gradient in addition to numerous other proteins (Fig. 9b, lane 15; p68 was identified by immunoblotting with antibody PI1). When the fractions containing p68 were pooled (fractions 12-20, Fig. 9) and

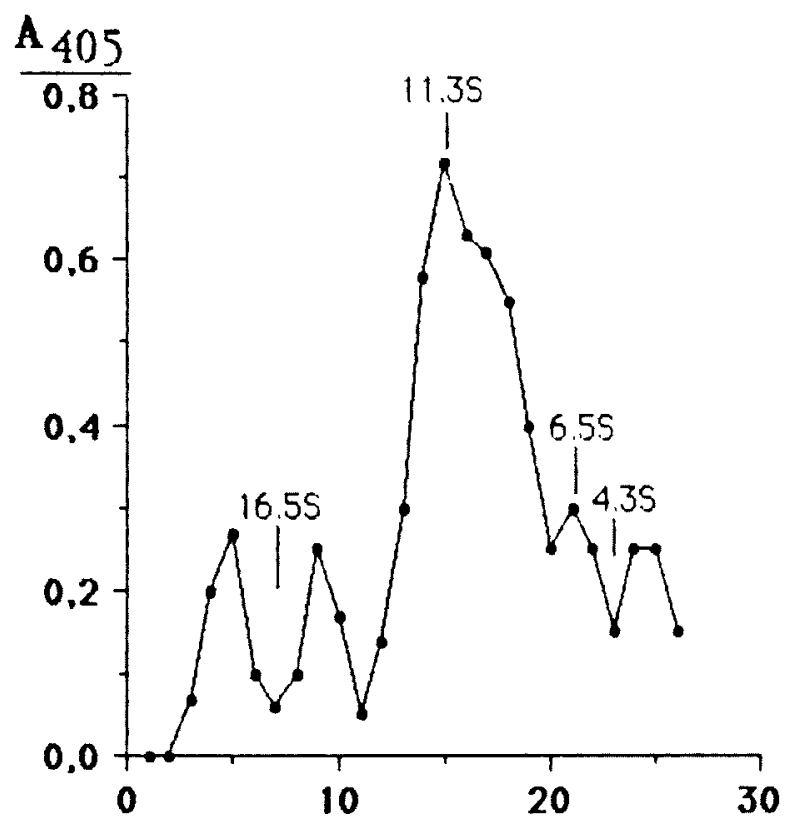

a

\section{FRACTION NO.}

\section{$\begin{array}{lllllllllllllll}1 & 3 & 5 & 7 & 9 & 11 & 13 & 15 & 17 & 19 & 21 & 23 & 25 & \text { E A }\end{array}$}

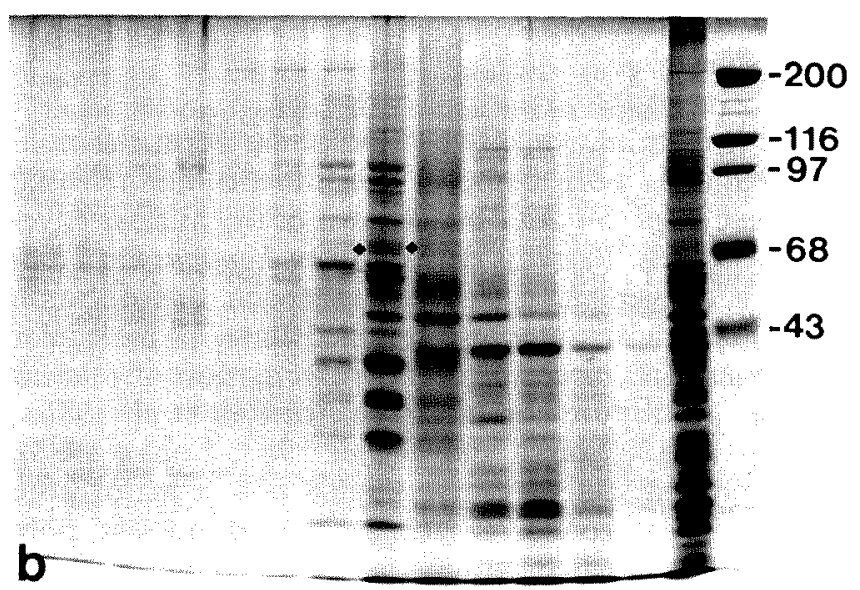

Fig. 9a, b. Sucrose gradient centrifugation of egg extract and ELISA assay $\left(\mathrm{A}_{405}\right)$ with antibody PII a. Sedimentation coefficients of reference proteins examined in parallel gradients are indicated. Proteins of individual sucrose gradient fractions were analysed by SDS-polyacrylamide gel electrophoresis and Coomassie blue staining $\mathbf{b}$. Fraction numbers are indicated at the tops of the lanes. Dots indicate p68 in lane 15 . E total extract. Molecular masses of the reference proteins $R$ are indicated in $\mathrm{kDa}$

further examined by gel filtration on a Sephadex G200 column, the p68 containing complex eluted with an apparent $\mathrm{M}_{\mathrm{r}}$ value of approximately 280,000 (Fig. 10). The combined data obtained by sucrose gradient centrifugation and gel filtration allowed an estimate of the mean $M_{r}$ value of the native complex $(254,000$; cf. Siegel and Monty 1966). The frictional ratio of the complex was 1.25 indicative of an almost globular supramolecular assembly with a Stokes radius of approximately $5.2 \mathrm{~nm}$. 


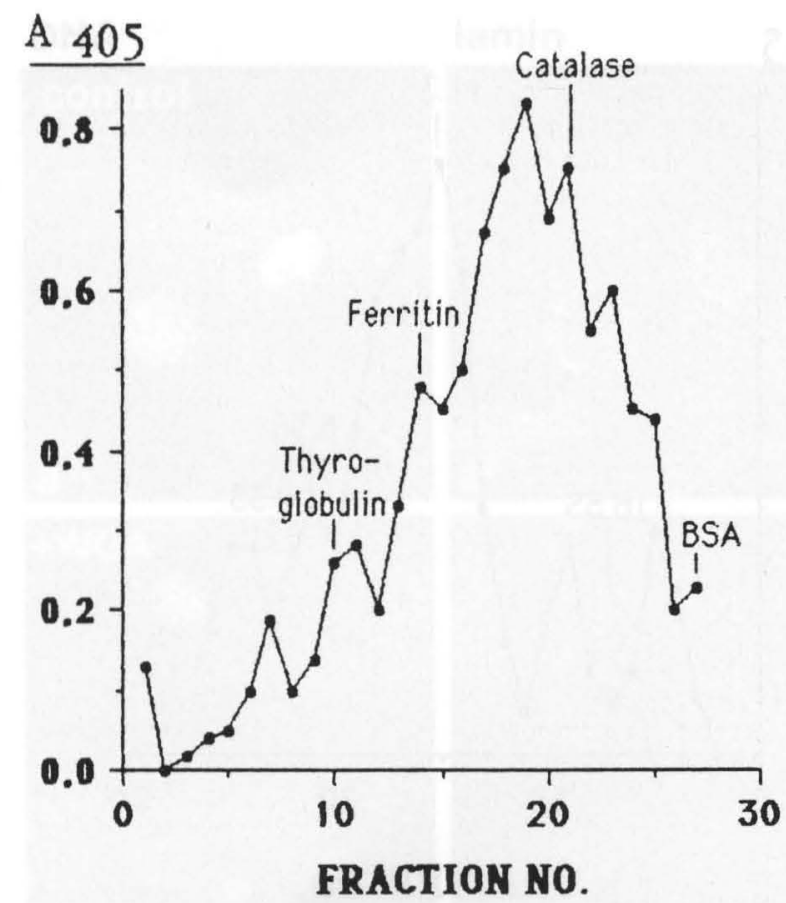

Fig. 10. Gel filtration of egg extract through a Sephadex G200 column and ELISA assay $\left(\mathrm{A}_{405}\right)$ with antibody PI1. Calibration of the column was performed with the reference proteins indicated

\section{Discussion}

So far it is unknown in what molecular form the nonmembraneous pore complex constituents are released into the cytoplasm after breakdown of the nuclear envelope at mitosis. Extracts derived from Xenopus eggs represent a convenient system to approach this question since they contain, in a disassembled state, all molecular components required for de novo formation of nuclear envelopes and pore complexes (Newmeyer et al. 1986a; Newport 1987; Lohka and Maller 1987; Lohka 1988). In the present study we investigated $\mathrm{p} 68$, a major pore complex glycoprotein. In the assembled nuclear pore complex it is located within the pore channel where it plays a critical role in transport processes of karyophilic proteins (Dabauvalle et al. 1988 b). In preliminary experiments we have recovered p68 from the soluble supernatant fraction after centrifugation of the egg extract at $100,000 \mathrm{~g}$ for $1 \mathrm{~h}$, indicating that $\mathrm{p} 68$ is not associated with membranes. It is known that the soluble as well as the sedimentable fraction enriched in membrane vesicles are required for in vitro formation of nuclear envelopes and pore complexes (Lohka and Masui 1984; Wilson and Newport 1988; Sheehan et al. 1988).

In order to characterize further the soluble form of p68 we immunoadsorbed the extract with monoclonal antibody PI1 conjugated to Sepharose. As a result, the depleted extract lost its ability to assemble pore complexes but could still support the formation of nuclear envelopes. Thus, nuclei reconstituted in an immunodepleted extract were surrounded by a continuous double membrane envelope but lacked pore complexes and were unable to take up karyophilic proteins such as nucleo- plasmin and lamin $\mathrm{L}_{\text {III }}$. These results clearly demonstrate that formation of the nuclear envelope and pore complexes are independent processes. Hence they do not support the recently proposed prepore model of nuclear envelope formation which postulates that prepores bind first to the chromatin surface and then act as receptors for membrane vesicle binding (Sheehan et al. 1988).

Whether or not nuclear membrane formation requires the presence of a lamina cannot be decided from our present data. At first sight the apparent absence of a lamina layer from the pore-deficient nuclei as judged by immunofluorescence microscopy seems to indicate that nuclear membrane assembly is independent of lamin formation. In fact it has been recently reported that membrane vesicles can bind directly to purified metaphase chromosomes via an interaction between membrane receptors and protein ligands on the chromatin surface (Newport and Dunphy 1989). However, we cannot exclude the possibility that some lamin molecules - undetectable by immunofluorescence microscopy first bind to the chromatin and form a kind of "minimal lamina" which, however, is sufficient to mediate membrane vesicle binding and fusion (see Gerace 1986; Lohka 1988).

When we used WGA instead of antibody PI1 to deplete the egg extract, we obtained essentially identical results. Our observation that removal of WGA-binding proteins from the extract efficiently prevented pore complex assembly contrasts with results published in the course of our experiments (Finlay and Forbes 1990). These authors reported that nuclei formed in WGA-depleted extracts contained approximately the same number of pore complexes as control nuclei. Despite the presence of pore complexes they found, in agreement with our results, that the nuclei were unable to transport karyophilic proteins and therefore concluded that the pores, which revealed a normal morphology, were biochemically altered. At the moment we cannot offer an explanation for these divergent results. In our hands, pore complexes do not form when (i) the extract is depleted of WGA-binding proteins, (ii) WGA is added to the complete extract and (iii) proteins binding to antibody PI1 are removed from the extract.

The antibody PI1 used in the present study recognizes a single nuclear pore complex glycoprotein (p68) of Xenopus oocytes as demonstrated by immunoblotting, immunofluorescence and immunogold electron microscopy (Dabauvalle et al. 1988 b). Our present results show that an additional protein of $\mathrm{M}_{\mathrm{r}} 42,000$ occurs in Xenopus oocytes and eggs which cross-reacts with the antibody in immunoblots. However, since this protein is located exclusively in the cytoplasm of Xenopus oocytes it cannot form part of the nuclear pore complexes. Antibody PI1 not only adsorbed p68 out of the extract but also at least three other proteins, notably two high molecular weight components which were not labelled in immunoblots. In order to clarify whether these additional proteins were coadsorbed because of a tight physical association with $\mathrm{p} 68$, we performed sucrose gradient and gel filtration experiments. The combined results indicate that p68 occurs in the form of approximately spherical 
complexes of $M_{r} 254,000$ with a Stokes radius of 5.2 $\mathrm{nm}$ and a sedimentation coefficient of $11.3 \mathrm{~S}$. It is conceivable that these complexes are represented by the 12 $15 \mathrm{~nm}$ particles attached to the surface of the antibody aggregates shown in Fig. 3 a.

We note that the molecular mass of the p68-containing complex as calculated from sucrose gradient and gel filtration experiments is difficult to reconcile with the immunoadsorption data. A supramolecular complex consisting of a single molecule each of p68 and the three other polypeptides recovered in the immunoprecipitate (Fig. 7, lane 4, arrows) should considerably exceed a molecular mass of 254,000 . We surmise that antibody PI1 also binds, under the conditions of immunoadsorption, other glycoproteins not associated with p68 since the GlcNAc sugar moiety forms part of the immunological determinant (Dabauvalle et al. 1988b). In order to identify unequivocally the protein(s) associated with p68 and to clarify whether they are also constituents of pore complexes it will be necessary to purify the p68 complexes as far as possible prior to immunoprecipitation.

Our finding that p68 is stored in the egg cytosol as a larger and stable macromolecular assembly is consistent with the cytological distribution of p68 during mitosis. Immunofluorescence microscopy reveals a distinctly punctate pattern indicating that p68 is released upon nuclear envelope breakdown into the cytoplasm of $\mathrm{PtK}_{2}$ cells in the form of discrete entities (Benavente et al. 1989a). Antibodies reacting with other members of the GlcNAc-containing pore complex glycoprotein family show a similar dispersed punctate pattern in mitotic cells (Snow et al. 1987).

Further investigations are now in progress to characterize in detail the molecular composition of the soluble p68-containing complexes in relation to assembled pores, the forces that keep these complexes together, their relationship to the transport machinery located in the pore channel and their mode of release from and reinsertion into the nuclear membranes during mitosis.

Acknowledgements. We thank Hilde Merkert for excellent technical assistance. This work received financial support from the Deutsche Forschungsgemeinschaft (SFB 176).

\section{References}

Benavente R, Krohne G, Franke WW (1985) Cell type-specific expression of nuclear lamina protein during development of Xenopus laevis. Cell 41:177-190

Benavente R, Dabauvalle MC, Scheer U, Chaly N (1989a) Functional role of newly formed pore complexes in postmitotic nuclear reorganization. Chromosoma 98:233-241

Benavente R, Scheer U, Chaly N (1989b) Nucleocytoplasmic sorting of macromolecules following mitosis: fate of nuclear constituents after inhibition of pore complex function. Eur J Cell Biol 50:209-219

Chaly N, Bladon T, Setterfield G, Little JE, Kaplan JG, Brown DL (1984) Changes in distribution of nuclear matrix antigens during the mitotic cell cycle. J Cell Biol 99:661-671

Chaly N, Sabour MP, Silver JC, Aitchison WA, Little JE, Brown DL (1986) Monoclonal antibodies against nuclear matrix detect nuclear antigens in mammalian, insect and plant cells: an immunofluorescence study. Cell Biol Int Rep 10:421-428

Dabauvalle MC, Schulz B, Scheer U, Peters R (1988a) Inhibition of nuclear accumulation of karyophilic proteins in living cells by microinjection of the lectin wheat germ agglutinin. Exp Cell Res 174:291-296

Dabauvalle MC, Benavente R, Chaly N (1988b) Monoclonal antibodies to a $M_{r} 68,000$ pore complex glycoprotein interfere with nuclear protein uptake in Xenopus oocytes. Chromosoma 97:193-197

Davis LI, Blobel G (1986) Identification and characterization of a nuclear pore complex protein. Cell 45:699-709

Davis LI, Blobel G (1987) Nuclear pore complex contains a family of glycoproteins that includes $\mathrm{p}$ 62: glycosylation through a previously unidentified cellular pathway. Proc Natl Acad Sci USA $84: 7552-7556$

Featherstone C, Darby MK, Gerace L (1988) A monoclonal antibody against the nuclear pore complex inhibits nucleocytoplasmic transport of protein and RNA in vivo. J Cell Biol 107:1289-1297

Finlay DR, Forbes DJ (1990) Reconstitution of biochemically altered nuclear pores: transport can be eliminated and restored. Cell $60: 1-29$

Finlay DR, Newmeyer DD, Price TM, Forbes DJ (1987) Inhibition of in vitro nuclear transport by a lectin that binds to nuclear pores. J Cell Biol 104:189-200

Franke WW, Scheer U, Krohne G, Jarasch ED (1981) The nuclear envelope and the architecture of the nuclear periphery. $J$ Cell Biol $91: 39 \mathrm{~s}-50 \mathrm{~s}$

Gerace L (1986) Nuclear lamina and organization of nuclear architecture. Trends Biochem Sci 11:443-446

Gerace L, Burke B (1988) Functional organization of the nuclear envelope. Annu Rev Cell Biol 4:335-374

Gerace L, Ottaviano Y, Kondor-Koch C (1982) Identification of a major polypeptide of the nuclear pore complex. J Cell Biol 95:826-837

Hanover JA, Cohen CK, Willingham MC, Park MK (1987) Olinked $\mathrm{N}$-acetylglucosamine is attached to proteins of the nuclear pores. J Biol Chem 262:9887-9894

Hart GW, Haltiwanger RS, Holt GD, Kelly WG (1989) Glycosylation in the nucleus and cytoplasm. Annu Rev Biochem 58:841874

Hautanen A, Linder E (1981) C3c-binding Elisa for detection of immunoconglutins and immunoglobulin aggregates. Methods Enzymol 74:588-607

Hawkes R, Niday E, Gordon J (1982) A dot-immunobinding assay for monoclonal and other antibodies. Anal Biochem 119:142147

Holt GD, Snow CM, Senior A, Haltiwanger RS, Gerace L, Hart GW (1987) Nuclear pore complex glycoproteins contain cytoplasmically disposed $\mathrm{O}$-linked $\mathrm{N}$-acetylglucosamine. J Cell Biol 104:1157-1164

Karsenti E, Newport J, Hubble R, Kirschner M (1984) Interconversion of metaphase and interphase microtubule arrays, as studied by the injection of centrosomes and nuclei into Xenopus eggs. J Cell Biol 98:1730-1745

Kessel RG (1988) The contribution of the nuclear envelope to eukaryotic cell complexity: architecture and functional roles. CRC Crit Rev Anat Cell Biol 1:327-423

Kessel RG (1989) The annulate lamellae - from obscurity to spotlight. Electron Microsc Rev 2:257-348

Krohne G, Franke WW (1980) A major soluble acidic protein located in nuclei of diverse vertebrate species. Exp Cell Res 129:167-189

Krohne G, Dabauvalle MC, Franke WW (1981) Cell type-specific differences in protein composition of nuclear pore complexlamina structures in oocytes and erythrocytes of Xenopus laevis. J Mol Biol 151:121-141

Krohne G, Waizenegger I, Höger TH (1989) The conserved carboxy-terminal cysteine of nuclear lamins is essential for lamin association with the nuclear envelope. J Cell Biol 109:20032011

Laemmli UK (1970) Cleavage of structural proteins during the assembly of the head of bacteriophage $T_{4}$. Nature 277:680-685 
Lohka MJ (1988) The reconstitution of nuclear envelopes in cellfree extracts. Cell Biol Int Rep 12:833-848

Lohka MJ, Maller JL (1987) Regulation of nuclear formation and breakdown in cell-free extracts of amphibian eggs. In: Schlegel RA, Halleck MS, Rao PN (eds) Molecular regulation of nuclear events in mitosis and meiosis, Academic Press, Orlando, pp $67 \sim 109$

Lohka MJ, Masui Y (1983) Formation in vitro of sperm pronuclei and mitotic chromosomes induced by amphibian ooplasmic components. Science 220:719-721

Lohka MJ, Masui Y (1984) Roles of cytosol and cytoplasmic particles in nuclear envelope assembly and sperm pronuclear formation in cell-free preparations from amphibian eggs. J Cell Biol 98:1222-1230

Maul GG (1977) The nuclear and the cytoplasmic pore complex: structure, dynamics, distribution, and evolution. Int Rev Cytol $6: 75-186$

Newmeyer DD, Forbes DJ (1988) Nuclear import can be separated into distinct steps in vitro: nuclear pore binding and translocation. Cell 52:641-653

Newmeyer DD, Lucocq JM, Bürglin TR, De Robertis EM (1986a) Assembly in vitro of nuclei active in nuclear protein transport: ATP is required for nucleoplasmin accumulation. EMBO $J$ $5: 501-510$

Newmeyer DD, Finlay DR, Forbes DJ (1986b) In vitro transport of a fluorescent nuclear protein and exclusion of non-nuclear proteins. J Cell Biol 103:2091-2102

Newport J (1987) Nuclear reconstitution in vitro: stages of assembly around protein-free DNA. Cell 48:205-217

Newport J, Dunphy DG (1989) Molecular components involved in nuclear envelope assembly. J Cell Biol 109:192a

Newport J, Forbes DJ (1987) The nucleus: structure, function, and dynamics. Annu Rev Biochem 56:535-565

Newport J, Spann T (1987) Disassembly of the nucleus in mitotic extracts: membrane vesicularization, lamin disassembly, and chromosome condensation are independent processes. Cell $48: 219-230$

Park MK, D'Onofrio M, Willingham MC, Hanover JA (1987) A monoclonal antibody against a family of nuclear pore proteins (nucleoporins): $\mathrm{O}$-linked $\mathrm{N}$-acetylglucosamine is part of the immunodeterminant. Proc Natl Acad Sci USA 84:6462 6466

Roos UP (1973) Light and electron microscopy of rat kangaroo cells in mitosis. I. Formation and breakdown of the mitotic apparatus. Chromosoma 40:43-82

Scheer U, Messner K, Hazan R, Raska I, Hansmann P, Falk H, Spiess E, Franke WW (1987) High sensitivity immunolocaliza- tion of double and single-stranded DNA by a monoclonal antibody. Eur J Cell Biol 43:358-371

Scheer U, Dabauvalle MC, Merkert H, Benavente R (1988) The nuclear envelope and the organization of the pore complexes. Cell Biol Int Rep 12:669-689

Sheehan MA, Mills AD, Sleeman AM, Laskey RA, Blow JJ (1988) Steps in assembly of replication-competent nuclei in a cell-free system from Xenopus eggs. J Cell Biol 106:1-12

Siegel LM, Monty KJ (1966) Determination of molecular weights and frictional ratios of proteins in impure systems by use of gel filtration and density gradient centrifugation. Biochim Biophys Acta 112:346-362

Snow CM, Senior A, Gerace L (1987) Monoclonal antibodies identify a group of nuclear pore complex glycoproteins. J Cell Biol 104: $1143-1156$

Stafstrom JP, Staehelin A (1984) Dynamics of the nuclear envelope and of nuclear pore complexes during mitosis in the Drosophila embryo. Eur J Cell Biol 34:179-189

Stanker LH, Nander CM, Juarez-Salinas H (1985) One-step purification of mouse monoclonal antibodies from ascites by hydroxylapatite chromatography. J Immunol Methods 76: 157-169

Stick R, Hausen P (1985) Changes in the nuclear lamina composition during early development of Xenopus laevis. Cell 41:191 200

Switzer RC, Merril CR, Shifrin S (1979) A highly sensitive silver stain for detecting proteins and peptides in polyacrylamide gels. Anal Biochem 98:231-237

Szollosi D, Calarco PG, Donahue RP (1972) The nuclear envelope: Its breakdown and fate in mammalian oogonia and oocytes. Anat $\operatorname{Rec} 174: 325-430$

Towbin H, Stachelin T, Gordon J (1979) Electrophoretic transfer of proteins from polyacrylamide gels to nitrocellulose sheets: procedure and some applications. Proc Natl Acad Sci USA $76: 4350-4354$

Wilson KL, Newport J (1988) A trypsin-sensitive receptor on membrane vesicles is required for nuclear envelope formation in vitro. J Cell Biol 107:57-68

Wolff B, Willingham MC, Hanover JA (1988) Nuclear protein import: specificity for transport across the nuclear pore. Exp Cell Res 178:318-334

Yoneda Y, Imamoto-Sonobe N, Yamaizumi M, Uchida T (1987) Reversible inhibition of protein import into the nucleus by wheat germ agglutinin injected into cultured cells. Exp Cell Res 173:586-595

Zatsepina OV, Polyakov VYu, Chentsov YuS (1977) Some structural aspects of the fate of the nuclear envelope during mitosis. Eur J Cell Biol 16:130-144 